\title{
Some Brief Notes on Theoretical and Experimental Investigations of Intramolecular Hydrogen Bonding
}

\author{
Lucjan Sobczyk ${ }^{1}$, Dorota Chudoba ${ }^{2,3}$, Peter M. Tolstoy ${ }^{4}$ and Aleksander Filarowski ${ }^{1,3, *}$ \\ 1 Faculty of Chemistry, University of Wrocław, 14 F. Joliot-Curie Str., 50-383 Wrocław, Poland; \\ lucjan.sobczyk@chem.uni.wroc.pl \\ 2 Faculty of Physics, A. Mickiewicz University, Umultowska 85, 61-614 Poznan, Poland; dmn@amu.edu.pl \\ 3 Frank Laboratory of Neutron Physics, Joint Institute for Nuclear Research, 141980 Dubna, Russia \\ 4 Center for Magnetic Resonance, St. Petersburg State University, St. Petersburg 198504, Russia; \\ peter.tolstoy@spbu.ru \\ * Correspondence: aleksander.filarowski@chem.uni.wroc.pl; Tel.: +48-71-3757229; Fax: +48-71-3282348
}

Academic Editor: Steve Scheiner

Received: 22 October 2016; Accepted: 28 November 2016; Published: 2 December 2016

\begin{abstract}
A review of selected literature data related to intramolecular hydrogen bonding in ortho-hydroxyaryl Schiff bases, ortho-hydroxyaryl ketones, ortho-hydroxyaryl amides, proton sponges and ortho-hydroxyaryl Mannich bases is presented. The paper reports on the application of experimental spectroscopic measurements (IR and NMR) and quantum-mechanical calculations for investigations of the proton transfer processes, the potential energy curves, tautomeric equilibrium, aromaticity etc. Finally, the equilibrium between the intra- and inter-molecular hydrogen bonds in amides is discussed.
\end{abstract}

Keywords: intramolecular hydrogen bond; Schiff base; Mannich base; proton sponge; acetophenone; salicylamide; pyridoxal

\section{Introduction}

This paper reports on the studies of the systems with intramolecular hydrogen bonding by experimental (IR, NMR, UV-Vis, X-ray and IINS) and theoretical (DFT, ab initio, AIM) methods. As the primary objects for this short review we have selected Schiff bases, Mannich bases, ortho-hydroxyaryl ketones and amides, as well as some proton sponges. A majority of the presented studies covers the phenomena of proton transfer (PT), steric effect, quasi-aromatic hydrogen bonding, aromaticity, tautomeric and conformational equilibria. It should be stressed that the studies of the proton transfer process are of great importance in the description of some enzymatic reactions activated by the hydrogen bonding with a low barrier proton transfer [1-3]. The studies of the ortho-hydroxyaryl Schiff bases can greatly contribute to the understanding of mechanisms of activity of some drugs as well as support the design of new ones [4,5]. For instance, ortho-hydroxyaryl Schiff thiosemicarbazones intercalate between the nitrogen bases in double DNA helix blocking the replication. This feature enables these compounds to be used in the treatment of cancer diseases. There are also substances with ortho-hydroxyaldiminecarbazyne structure which coordinate the iron atoms [6,7]. Their presence in the organism regulates the amount of iron in cells, thus preventing the formation of cancer cells. It is important to note that the salicylamides are nonsteroidal anti-inflammatory medicaments. The modelling of the physicochemical features of salicylamides makes it possible to describe the mechanisms of their biological activity. The major types of compounds with intramolecular hydrogen bonds which are discussed in this review (compounds 1-5) are shown in Figure 1. 
<smiles>[R2]C1=NC[Tl]c2ccccc21</smiles>

1

ortho-hydroxyaryl Schiff bases<smiles>[R]C1=CO[CH]c2ccccc21</smiles>

2

ortho-hydroxyaryl aldehydes and ketones<smiles></smiles>

3

ortho-hydroxyaryl amides

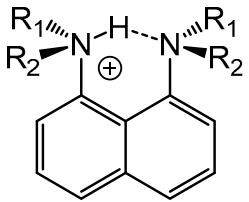

4

$\mathrm{N}, \mathrm{N}$-dialkylaminonaphthalene (proton sponge)<smiles>[R2][N+]1([R])COc2ccccc2C1</smiles>

5

ortho-hydroxyaryl Mannich bases

Figure 1. Schematic structures of compounds discussed in this work. $R_{1}$ and $R_{2}=$ hydrogen, aryl and alkyl substitutions.

\section{Study of Proton Transfer Process in Hydrogen Bridge by Quantum-Mechanical Methods}

To study the energetic and geometric properties of intramolecular hydrogen bonds a full spectrum of quantum-mechanical methods could be applied. Concerning the choice of the method and the basis set, usually the recommendations are the same as for other types of H-bonded systems. The level of theory is often limited by the size of the molecule in question. Though MP2 performs admirably [8], the cost-effective DFT methods (usually with B3LYP and PBE functionals) perform quite good as well [9]. The basis set preferably should include diffuse functions. While basis sets such as aug-cc-pVTZ are desired, it seems that $6-311++G(d, p)$ remains one of the most widely used basis sets up to now. Bader's "Atoms in Molecules" calculations are often used to estimate the hydrogen bond strength. Calculations are usually performed for isolated molecules, while medium effects are treated by polarized continuum models (PCM) or including one or several solvent molecules explicitly in calculations [10].

\section{Ortho-Hydroxyaryl Schiff Bases 1}

The papers [11-16] present the quantum-mechanical calculations of ortho-hydroxyaryl Schiff bases 1 showing the influence of the proton transfer in quasi-aromatic hydrogen bonds on the shape of the potential energy curve as well as on the electron density in critical points of bonds and rings. The authors of [11] elaborated the methodology of the calculations of spectroscopic features and potentials for proton motion in hydrogen bonds. The adiabatic and the non-adiabatic potentials and energy levels for a number of ortho-hydroxyaryl ketimines and their deuterated analogues were calculated. From the energy levels, the positions of $v(\mathrm{XH})$ bands and the H/D isotope effects on them were estimated. Estimation of the anharmonic $v(\mathrm{XH})$ stretching vibration frequency for the $\mathrm{XH}$ bond engaged in hydrogen bond formation is a valuable result because computational programs with standard methods usually do not provide a sufficiently precise description of the $v(\mathrm{XH})$ band position. In $[11,12,15]$ the calculations of the non-adiabatic potential along the bridging proton transfer coordinate were based on the optimization of all the parameters of the molecule for the gradually elongated $\mathrm{XH}$ bond. This approach serves for the description of the changes of structural parameters during the transition from the molecular form to the proton transfer form. It was shown that the proton transfer process leads to the shortening and strengthening of the hydrogen bonding in the first phase of this phenomenon (going from the molecular form to the transition state), and the lengthening in the second phase (going from the transition state to the PT form) (Figure 2).

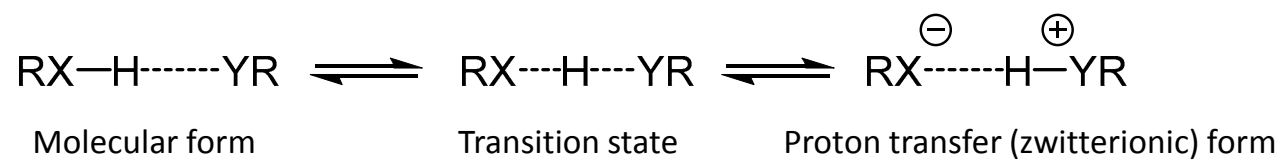

Figure 2. Transition from the molecular form to the proton transfer (zwitterionic) form of the hydrogenbonded complex. 
The paper [11] presents the computational study of the influence of the environment polarity on the potential energy profile for the proton transfer process. The lowering of the energy minimum for the PT form upon increase of the environment polarity for non-adiabatic potential is shown. A similar trend of the adiabatic potential for the molecular form is observed. However, untypical increase of the local minimum of the adiabatic potential for the PT form with the increase of the solvent polarity was also presented.

To describe the changes in the electron densities taking place in a molecule during the proton transfer in hydrogen bridge the "Atoms in Molecules" (AIM) method developed by Bader was applied [12,17-23]. The changes in the electronic density in the bond critical points (including hydrogen bonds and rings) in the non-adiabatic approach for 2-[(1E)-N-methyl-ethanimidoyl)]-phenol $\left(\mathbf{1}, \mathrm{R}_{1}=\mathrm{R}_{2}=\mathrm{CH}_{3}\right.$; Figure 1) are analysed in [12]. New correlations were obtained and the dependencies presented in the literature [23] were verified. The dependency of the electronic density in the critical point of the chelate chain $(\mathrm{O}-\mathrm{C}=\mathrm{C}-\mathrm{C}=\mathrm{N})$ on the length of $\mathrm{XH}$ bonding is shown in Figure 3. The electron density at the hydrogen bond critical point goes through a maximum for the transition state (Figure 2), which corresponds to the most linear and shortest hydrogen bridge [24]. It can be seen that the application of the third state is necessary for the description of the tautomeric equilibrium. According to the studies of the potentials this state corresponds to the transition state (Figure 2).

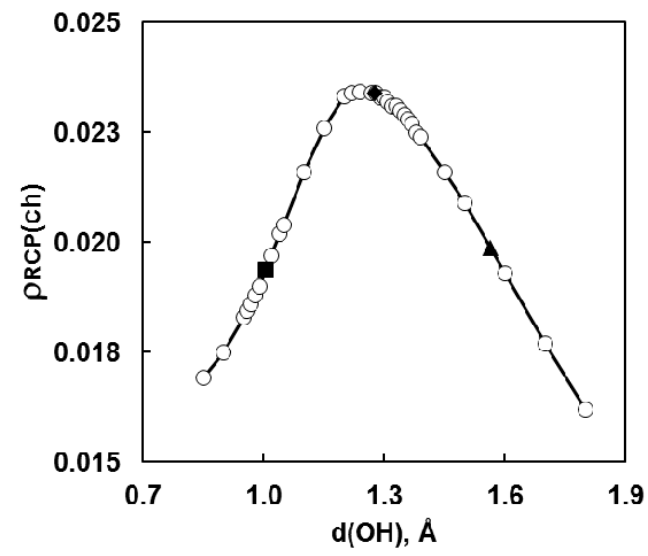

Figure 3. The dependence of the electron densities in the critical point of the quasi-aromatic ring $(\mathrm{HO}-\mathrm{C}=\mathrm{C}-\mathrm{C}=\mathrm{N}$ ) on the length of hydroxyl bond of the ortho-hydroxyaryl Schiff base $\mathbf{1}$ (Figure 1,

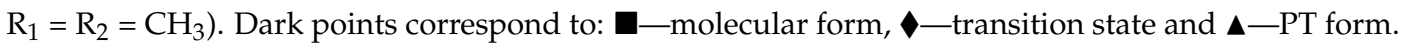
Reprinted with permission from [12]. Copyright 2008 American Chemical Society.

\section{Spectroscopic Studies of Tautomeric Equilibrium in Intramolecular Hydrogen Bonds}

According to a recent IUPAC recommendation, the NMR and IR signatures of a hydrogen bond are the main spectroscopic criteria of its formation $[25,26]$. As a result, in practice the properties of intramolecular H-bonded systems are often studied experimentally using the values of vibrational frequencies, NMR chemical shifts and coupling constants. As for the majority of $\mathrm{H}$-bonded complexes, in systems discussed here upon formation of the intramolecular hydrogen bond the $v(X H)$ frequency decreases, while the chemical shifts of the bridging proton increases. Interpretation of these spectroscopic changes in terms of hydrogen bond geometry and energy might be done using previously published correlational dependencies [27-36]. Despite the typical spectroscopic manifestations of the intramolecular hydrogen bonds, the situation is often complicated by the presence of a tautomeric equilibrium between molecular of proton-transfer form of the complex (except for proton sponges, where both forms are positively charged). The equilibrium constant as well as the characteristics of individual tautomers are temperature-, solvent- and substituent-dependent. Disentangling the overall spectroscopic patterns requires a careful analysis and usage of other spectroscopic markers, such as, 
i.e., UV-Vis band positions and intensities, $\mathrm{C}=\mathrm{O}$ stretching frequencies, ${ }^{13} \mathrm{C}-,{ }^{15} \mathrm{~N}-\mathrm{NMR}$ chemical shifts, spin-spin coupling constants and $\mathrm{H} / \mathrm{D}$ isotope effects on all of the abovementioned parameters.

\subsection{Ortho-Hydroxyaryl Schiff Bases 1}

Spectroscopic studies including IR and Raman spectroscopic data as well as incoherent inelastic neutron scattering (IINS) data were presented in the literature [37-44]. These studies were based on a series of spectra recorded under the argon matrix condition, in the gas phase and the solid state. A detailed analysis of vibration spectra was also carried out by quantum-mechanical calculations. The effects of deuteration on band positions and intensities were investigated for the cases of deuteration in the hydrogen bridges and in the methyl group of imine fragments $\left(\mathrm{N}=\mathrm{C}-\mathrm{CH}_{3}\right)$ in ortho-hydroxyaryl ketimines $\left(\mathbf{1}, \mathrm{R}_{2}=\mathrm{CH}_{3}\right.$; Figure 1$)$. The position of the $v(\mathrm{C}-\mathrm{O})$ band turns out to be sensitive to the deuteration in the hydrogen bridge for the molecular form, while for the PT form the deuteration influences the $v(\mathrm{C}=\mathrm{N})$ band. This effect makes it possible to estimate the proton position in the hydrogen bridge.

In [45-47] various solutions of partially deuterated and ${ }^{15} \mathrm{~N}$-labelled ortho-hydroxyaryl Schiff bases 6 (Figure 4) were studied by ${ }^{1} \mathrm{H}$ - and ${ }^{15} \mathrm{~N}-\mathrm{NMR}$ spectroscopy, revealing the presence of intramolecular proton tautomerism between molecular (enol-imine) and zwitterionic (keto-amine) forms.

6

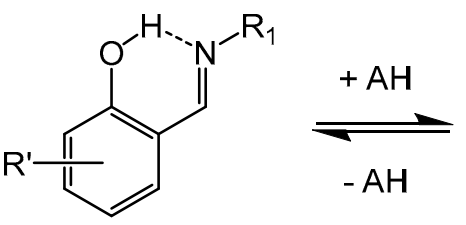

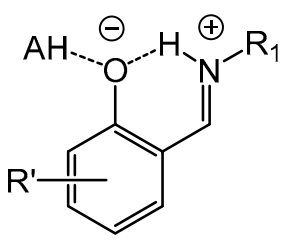

Figure 4. Schematic structure of ortho-hydroxyaryl Schiff bases, studied by NMR in [46].

The analysis of substituent- and temperature- dependent ${ }^{1} \mathrm{H}$ and ${ }^{15} \mathrm{~N}$ chemical shifts has revealed that upon the increase of the solvent polarity two effects are present: (i) shift of the tautomeric equilibrium towards the zwitterionic structures and (ii) changes in the hydrogen bond geometry in each of the tautomers. Namely, the hydrogen bond in the molecular form becomes stronger (symmetrization of the bridging proton position) while that in the zwitterionic tautomer becomes weaker (asymmetrization). A similar effect was later observed for other strongly hydrogen bonded systems and it was ascribed to the non-specific [48,49] or in some cases to specific [50] solvent-solute interactions. For ortho-hydroxyaryl Schiff bases 6 (Figure 4) the formation of additional hydrogen bonds to the phenol/phenolate oxygen atom by one or several alcohol molecules was shown to induce the proton transfer and stabilization of the keto-amine form $[45,46]$.

In [51] the effect of an additional covalently linked carboxylic group on the intramolecular proton tautomerism in 2-carboxy-4-methyl-6-[(E)-(phenyliminio)methyl]phenolate (ortho-hydroxyaryl Schiff base, 7 , Figure 5) has been studied. It was shown that in a $\mathrm{CDF}_{3} / \mathrm{CDF}_{2} \mathrm{Cl}$ solution the additional $\mathrm{COOH}$ group forms an $\mathrm{OHO}$ hydrogen bond with the phenolic oxygen atom, which "pushes" the proton in the neighboring OHN bonds towards the nitrogen atom. As a result, 7 exists almost exclusively in a proton transfer form $\mathrm{OH} \cdots \mathrm{O}^{-} \cdots \mathrm{HN}^{+}$, in which two proton donors form coupled hydrogen bonds and compete for the central phenolate oxygen acceptor. 
<smiles></smiles>

Figure 5. Schematic structure of ortho-hydroxyaryl Schiff base 7, studied by NMR in [51].

An interesting case of proton tautomerism and hydrogen bond coupling is represented by pyridoxal 5'-phosphate (PLP), which forms ortho-hydroxyaryl Schiff bases 8 (Figure 6) as a cofactor of many enzymes and also during the course of its catalytic cycle (so called "internal" and "external" aldimines, respectively) [52].

Protonation states, hydrogen bond geometries and hydrogen bond coupling in PLP has been studied recently by NMR in aqueous solution [53,54], in aprotic medium [55], in solid state [56,57] and also in hydrophobic pockets of proteins (alanine racemase, AlaR, and aspartate aminotransferase, AspAT) $[58,59]$. It was demonstrated that the proton position in the intramolecular OHN bond is determined to a large extent by the additional bonds formed with the phenolic oxygen or pyridine nitrogen atoms of PLP. In both cases, the formation of additional hydrogen bonds shifts the equilibrium towards the catalytically active zwitterionic ketoamine form. For example, in AspAT the pyridine nitrogen atom of PLP is fully protonated by the $\mathrm{COOH}$ group of the neighboring aspartic acid side chain [58].

8<smiles>[R]Cc1cnc(C)c2c1C=NC[R]2</smiles>
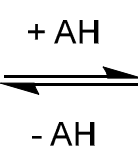<smiles>[R]Cc1c[n+]([Al])c(C)c2c1C=[N+]([R])[CH][CH]2</smiles>

Figure 6. Schematic structure of ortho-hydroxy Schiff bases 8, formed by PLP, studied by NMR ([59] and references cited therein).

\subsection{Ortho-Hydroxyaryl Aldehydes and Ketones 2}

Ortho-hydroxyaryl aldehydes and ketones are structurally close to ortho-hydroxyaryl Schiff bases, but they do not display proton transfer in the ground state [60-62]. The studies of two derivatives of ortho-hydroxyacetophenone (5-cyano-2-hydroxyacetophenone and 2-hydroxy-4-methoxy5-nitro-acetophenone) [62] which possess markedly strong acidity of the hydroxyl group failed to show the existence of the PT form in the ground state. Moreover, the investigation of fluorescent spectra recorded in solution and in the solid state show the prevailing of the PT form in the excited state for the ortho-hydroxyacyl aromatic compounds [63-65].

\subsection{Ortho-Hydroxyaryl Mannich Bases 5}

The studies of adiabatic potentials for the proton motion in 3,5,6-trimethyl-2- $(N, N-$ dimethylaminomethyl)phenol $\left(5, \mathrm{R}_{1}=\mathrm{R}_{2}=\mathrm{CH}_{3}\right.$; Figure 1$)$ and the description of infrared spectra by means of Car-Parrinello molecular dynamics (CPMD) is presented in [51]. The strengthening of the intramolecular hydrogen bond in this compound due to the steric effect of the methyl substituents in the phenyl ring was earlier stated and proved experimentally [66]. The aim of paper [67] was the verification of the conformity of the applied computational methods with the description of the intramolecular hydrogen bonding. The presented calculations for solution and solid states of 3,5,6-trimethyl-2-( $N, N$-dimethylamine-methyl)phenol by CPMD has allowed the authors to describe 
both spectral and structural parameters. The potential energy curves and corresponding vibrational energy levels estimated at B3LYP/cc-pVDZ and MP2/cc-pVDZ levels of theory for the adiabatic proton movement also made it possible to calculate the position of the $v(\mathrm{OH})$ stretching band. It was stated that the resulting calculated frequency is in a satisfactory agreement with experimental data. It should be underlined that CPMD method allows to study chemical reactions dynamically and to compute free energy profiles via thermodynamic integration of fluctuations and, therefore, to calculate entropy [68]. In $[69,70]$ the potential energy curves of proton transfer in intramolecular hydrogen bond in ortho-hydroxyaryl Schiff base [69] and acetic acid dimer [70] were studied, and the consistency of CPMD method was shown.

In liquid-state NMR spectra of ortho-hydroxyaryl Mannich bases the intramolecular OHN hydrogen bond manifests itself by a low-field shift of the bridging proton signal [71-74] and in some cases by the inversion of the sign of H/D isotope effects on ${ }^{13} \mathrm{C}-\mathrm{NMR}$ chemical shifts upon temperature decrease [75]. The latter is associated with the shift of the proton equilibrium from the molecular $\mathrm{OH} \cdots \mathrm{N}$ form to the zwitterionic $\mathrm{O}^{-} \cdots \mathrm{HN}^{+}$form. In [74] compound 9 (Figure 7) was studied by a combination of NMR and UV/Vis spectroscopy showing that in a polar aprotic medium such as a mixture of Freon gases $\mathrm{CDF}_{3} / \mathrm{CDF}_{2} \mathrm{Cl}$ the molecule exists in a molecular $\mathrm{OH} \cdots \mathrm{N}$ form, which changes to the zwitterionic $\mathrm{O}^{-} \ldots \mathrm{HN}^{+}$form upon the formation of cyclic dimers (shown in Figure 7 , right). The existence of the zwitterionic forms for monomers of compound 9 was not confirmed.<smiles>[R2]N1Cc2c(Cl)cc(Cl)c(Cl)c2CN1[R]</smiles>

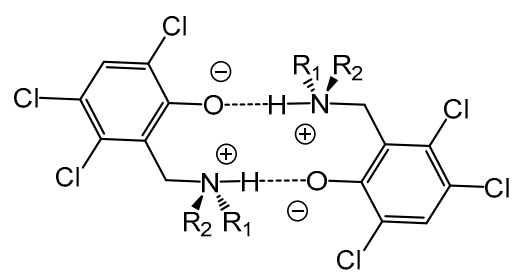

Figure 7. Schematic structure of ortho-hydroxyaryl Mannich base 9 (left) and its zwitterionic cyclic dimer (right), studied by NMR in [74].

\subsection{Dimethylaminonaphthalene (4)}

Dimethylaminonaphthalene, so-called proton sponge, is the subject of intensive studies [76-89]. In [76-80] the methods of synthesis, the analysis of the structural characteristics and the results of ab initio (MP2/6-31+G(d,p)) calculations for a series of dimethylaminonaphthalene derivatives are presented. It is noteworthy that the results of quantum-mechanical calculations and the interpretation of the NMR spectra of proton sponges with a strong buttressing effect coincide. For example, the calculated potential for the proton transfer for 2,7-dibromo-1,8-bis(dimethylamino)naphthalene is symmetric and possesses a low energy barrier (Figure 8) [79]. This result points out the delocalization of the proton in the hydrogen bridge which is in accordance with the record ${ }^{1} \mathrm{H}-\mathrm{NMR}$ chemical shift $\delta\left({ }^{1} \mathrm{H}\right)=21-22 \mathrm{ppm}[81,82]$ and a very high isotopic spectroscopic ratio, ISR $=v(\mathrm{NHN}) / v(\mathrm{NDN})=1.8[83]$. 


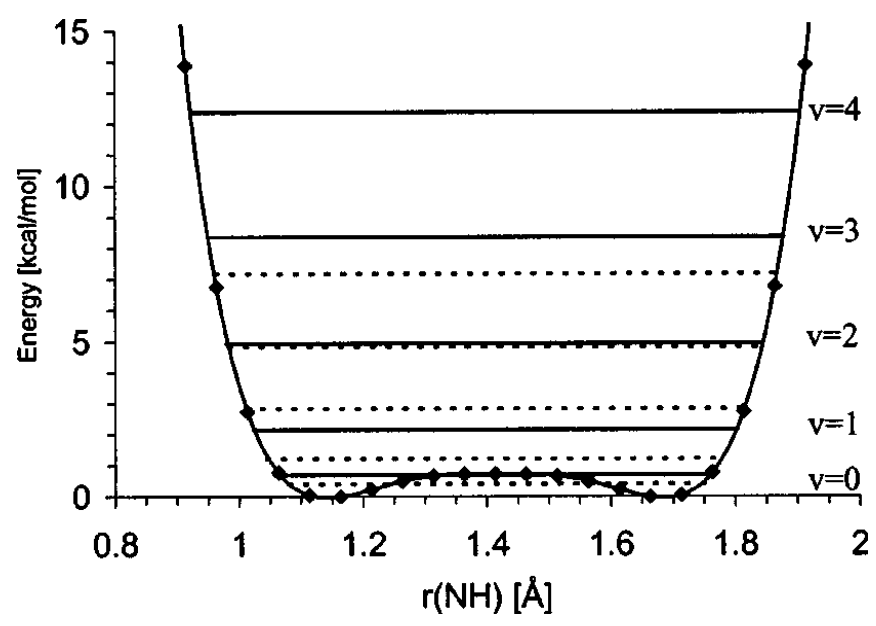

Figure 8. The potential energy curve for protonated 2,7-dibromo-1,8-bis(dimethylamino)naphthalene obtained by MP2/6-31+G(d,p) level of theory. Reprinted with permission from [79]. Copyright 2008 AIP Publishing.

The NMR studies of hydrogen bonding in proton sponges of type $\mathbf{1 0}$ (Figure 9) are mostly based on the interpretation of ${ }^{1} \mathrm{H}-,{ }^{15} \mathrm{~N}-\mathrm{NMR}$ chemical shifts, as well as ${ }^{1} J_{\mathrm{NH}},{ }^{1 \mathrm{~h}} J_{\mathrm{NH}}$ and ${ }^{2 \mathrm{~h}} J_{\mathrm{NN}}$ spin-spin coupling constants (the latter can be detected directly [84] or indirectly [68]) and H/D isotope effects on them.<smiles>[R]c1cc2c3c(cccc3c1)N(C)[C@@H](C)[N+]2C</smiles>

Figure 9. Schematic structure of protonated proton sponge 10, studied by NMR in [86].

In [86] the $(\mathrm{NHN})^{+}$hydrogen bond geometry and symmetry was studied depending on the solvent, counter-anion and temperature used (solvents: $\mathrm{CD}_{3} \mathrm{CN}, \mathrm{CD}_{2} \mathrm{Cl}_{2}$, toluene- $\mathrm{D}_{8}$ and $\mathrm{CDF}_{3} / \mathrm{CDF}_{2} \mathrm{Cl}$ mixture; counter-anions: $\mathrm{ClO}_{4}{ }^{-}$, trifluoroacetate $\left(\mathrm{TFA}^{-}\right)$, tetrakis[3,5-bis(trifluoro- methyl)phenyl]borate $\left.\left(\mathrm{BARF}^{-}\right)\right)$. It was shown that the positive charge in the $(\mathrm{NHN})^{+}$bond is well localized, indicating the presence of a degenerate tautomeric equilibrium between $\mathrm{NH}^{+} \ldots \mathrm{N}$ and $\mathrm{N} \cdots{ }^{+} \mathrm{NH}$ forms (asymmetric proton position was also detected in some proton sponges by dipolar solid-state NMR [87]). Lowering the temperature increases the symmetry of the hydrogen bond, as evidenced by the changes in NMR parameters; this phenomenon was attributed to the increase of the polar solvent ordering around the charged hydrogen bridge. It was also noticed that small counter-anions tend to perturb the hydrogen bond symmetry (presumably, due to the asymmetrical placement). In contrast, usage of large counter-anions with strongly delocalized negative charge leads to hydrogen bond symmetrization. A similar effect was studied later for other NHN-bonded systems $[88,89]$.

\section{Potential for Proton Transfer and Tautomeric Equilibrium}

The studies of the non-adiabatic potential for the proton transfer in ortho-hydroxyaryl Schiff bases [11,90], ortho-hydroxyaryl ketones [91], ortho-hydroxyaryl Mannich bases [66,92,93], dimethylaminonaphthalene [76-80] and ortho-hydroxyaryl amides [94] confirm the presence of the second local minimum on the potential curve for some ortho-hydroxyaryl Schiff bases and proton sponges (Figure 10), which allows one to observe tautomeric equilibrium. The potential energy curves do not exhibit a second a local minimum for ortho-hydroxyaryl amides, ortho-hydroxyaryl 
ketones, ortho-hydroxyaryl Mannich bases and, therefore, the experimental observation of the stable PT tautomeric form is not possible.

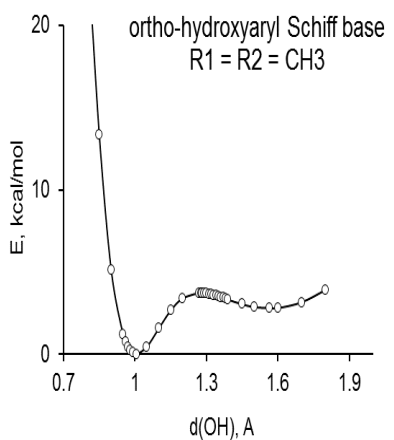

(A)

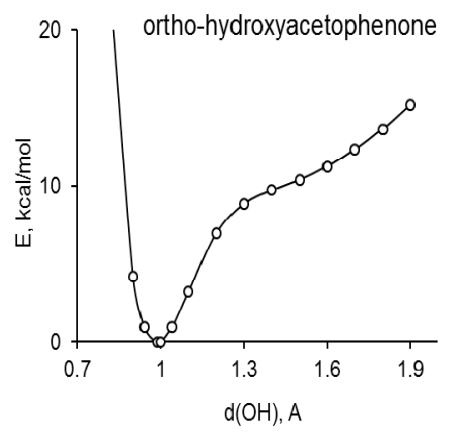

(D)

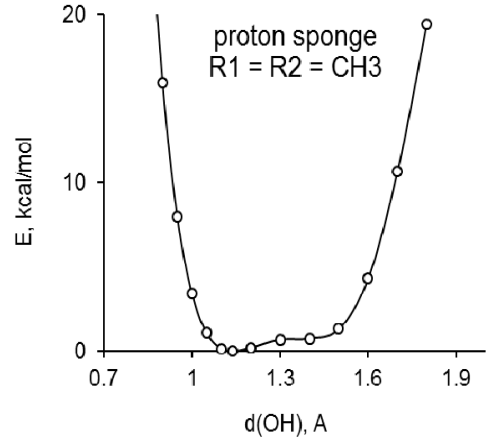

(B)

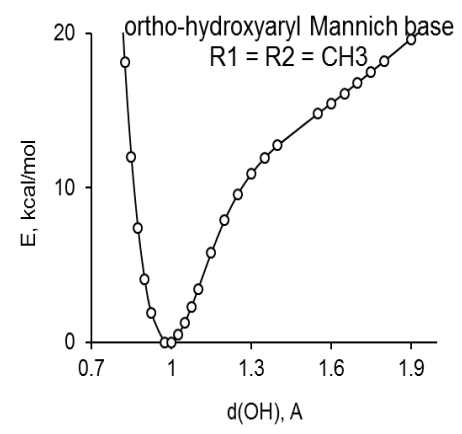

(E)

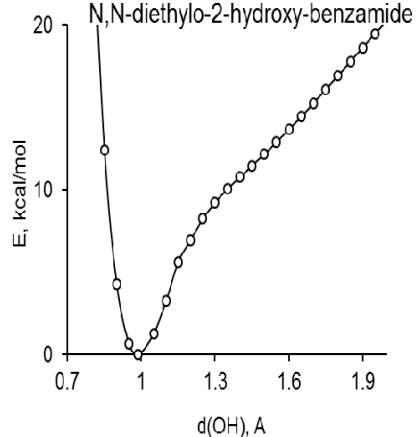

(C)

Figure 10. The non-adiabatic potential curves for: ortho-hydroxyaryl Schiff base $\left(\mathbf{1} ; \mathrm{R}_{1}=\mathrm{R}_{2}=\mathrm{CH}_{3}\right.$, Figure 1) (A); 1,8-bis(dimethylamino)-2,7-bis(trimethylsilyl)naphthalene (derivative of proton sponge) (4; $\mathrm{R}_{1}=\mathrm{R}_{2}=\mathrm{CH}_{3} ;$ Figure 1) (B); 2-hydroxy- $N$, $N$-diethylbenzamide $\left(3 ; \mathrm{R}_{1}=\mathrm{R}_{2}=\mathrm{C}_{2} \mathrm{H}_{5} ;\right.$ Figure 1$)$ (C); ortho-hydroxyacetophenone (2; $\mathrm{R}_{1}=\mathrm{CH}_{3}$; Figure 1) (D) and ortho-hydroxyaryl Mannich base $\left(5 ; \mathrm{R}_{1}=\mathrm{R}_{2}=\mathrm{CH}_{3} ;\right.$ Figure 1) (E).

\section{Proton Transfer Process and Aromaticity}

\section{Ortho-Hydroxyaryl Schiff Bases 1}

The formation of the intramolecular quasi-aromatic hydrogen bonding via $\pi$-electronic delocalization in the systems with the alternated double bonds (so-called chelate chain) stabilizes a flat conformation of a molecule and enforces hydrogen bonding. This effect is known as Resonance Assisted Hydrogen Bond (RAHB) [95]. From the point of view of the acid-base interactions, such strengthening of hydrogen bonding is caused by the mutual increase of basicity and acidity due to the $+\mathrm{M}$ and $-\mathrm{M}$ mesomeric effects via the chelate chain $[96,97]$. Recently, some literature sources have put in question the abovementioned point of view [98]. Yanez et al. [98] demonstrate that $\pi$-electronic conjugation does not strengthen hydrogen bonding. Obviously, the studies of aromaticity are very important for answering the question about the strengthening of hydrogen bonding in quasi-aromatic systems. References [99-103] dwell on the description of the aromaticity changes in systems with intramolecular hydrogen bonding depending on the state of tautomeric equilibrium. The papers [104-108] demonstrate that the parameters of aromaticity HOMA and HOSE [104] are reliable indicators in the estimation of tautomeric equilibrium. Based on X-ray diffraction data the correlations between the HOMA and HOSE aromaticity indexes and the $\mathrm{XH}$ bond length were obtained [100]. The phenyl and naphthalene derivatives of Schiff bases show the existence of aromaticity equilibrium, which reflects the decrease of aromaticity of the A ring with a little increase of aromaticity of the B ring under the proton transfer process 
$(\operatorname{HOMA}(\mathrm{A}, \mathrm{B})=f(\operatorname{HOSE}(\mathrm{ch}))$, Figure 11). It was stated that the change from the molecular form to the transition state triggers the increase of aromaticity of the chelate chain, and on the contrary, the change from the transition state to the PT form evokes the decrease of aromaticity $(\mathrm{HOMA}(\mathrm{ch})=\mathrm{f}(\mathrm{d}(\mathrm{OH}))$, Figure 11). It was also shown that the changes of aromaticity of the chelate chain (HOMA(ch)) depend in a non-linear way on the changes of aromaticity of the phenyl ring (or naphthalene ring $A$ ) under the proton transfer $(\mathrm{HOMA}(\mathrm{ph})=f(\operatorname{HOMA}(\mathrm{ch}))$, Figure 12$)$.

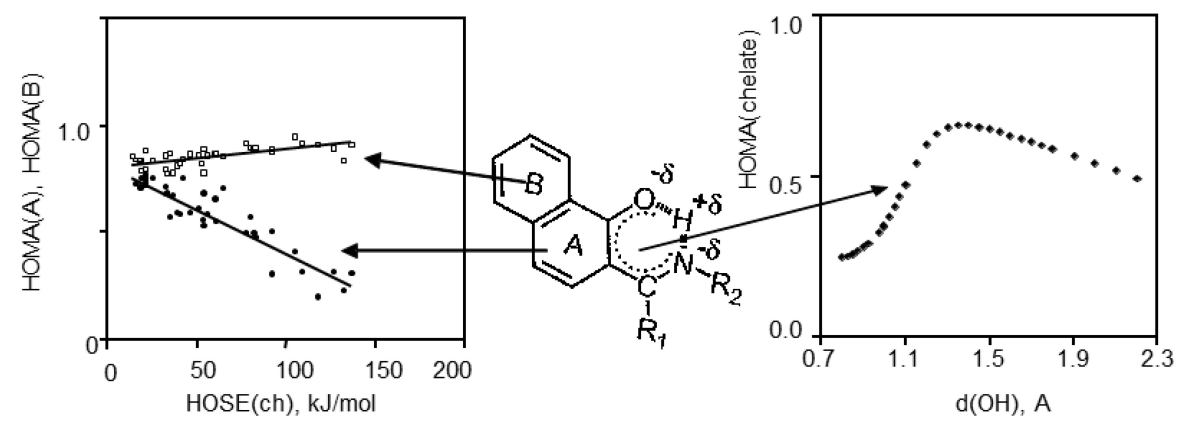

Figure 11. Left side: correlations between $\operatorname{HOMA}(\mathrm{A}), \mathrm{HOMA}(\mathrm{B})$ and $(\mathrm{HOSE}(\mathrm{ch}))$ aromaticity indexes calculated on the X-ray diffraction data. Reprinted with permission from [100]. Copyright 2008 John Wiley \& Sons, Ltd. Right side: dependency of the aromaticity of chelate chain (HOMA(ch)) depending on the $\mathrm{OH}$ bond length calculated on $\mathrm{MP} 2 / 6-31+(\mathrm{d}, \mathrm{p})$ data. $\mathrm{R}_{1}$ and $\mathrm{R}_{2}$ substitutions are hydrogen, alkyl and aryl substitutions.
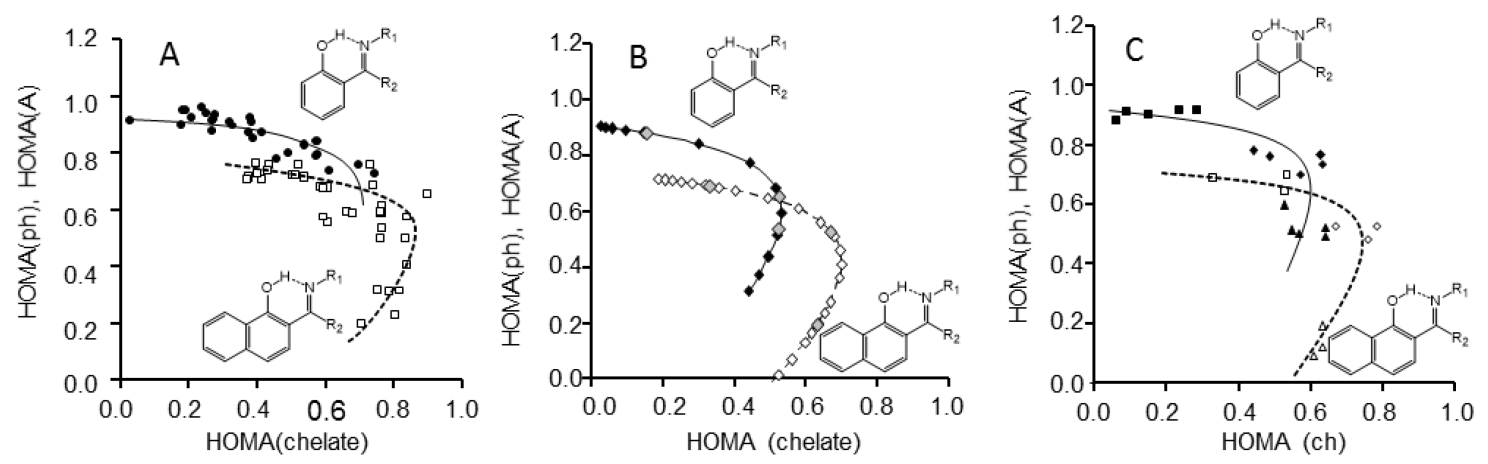

Figure 12. Dependencies of the HOMA aromaticity index of phenyl ring (HOMA(ph)) (solid line) and naphthalene (HOMA(A)) (dotted line) on the changes of aromaticity of chelate chain (HOMA(ch)) obtained from the experimental data (A); calculated with non-adiabatic approach for 2-[(1E)-Nmethylethanimidoyl]phenol $\left(\mathrm{R}_{1}=\mathrm{R}_{2}=\mathrm{CH}_{3}\right)$ and 2-[(1E)-1-(methyliminio)ethyl]-naphthalen-1-olate $\left(\mathrm{R}_{1}=\mathrm{R}_{2}=\mathrm{CH}_{3}\right)$ molecules $(\mathbf{B})$ and for fully optimised tautomeric form $(\mathbf{C})$.

An interesting fact is that the calculated results obtained by the non-adiabatic approach give a precise description of the aromaticity changes.

\section{Equilibrium between Different Intra-/Intra-Molecular Hydrogen Bonding and Intra-/Inter- Molecular Hydrogen Bonding}

\subsection{Ortho-Hydroxyaryl Aldehydes and Ketones 2}

The phenomenon of competition between two hydrogen bonds within one molecule is an interesting point to consider $[109,110]$. The competitive equilibrium between the $\mathrm{O}-\mathrm{H} \cdots \mathrm{O}_{2} \mathrm{~N}-$ and $\mathrm{O}-\mathrm{H} \cdots \mathrm{O}=\mathrm{C}$ hydrogen bonds in 5-methyl-3-nitro-2-hydroxyacetophenone (11) (Figure 13) by infrared spectroscopy and quantum-mechanical calculations is studied in [91,110]. 


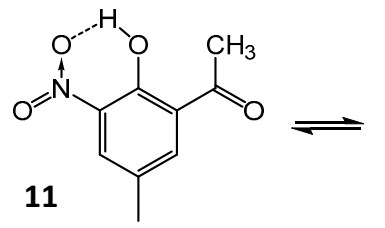<smiles>Cc1cc([N+](=O)[O-])c2occ(C)c2c1</smiles>

Figure 13. Scheme of the hydroxyl group isomerization in 5-methyl-3-nitro-2-hydroxyacetophenone (11).

The infrared spectra recorded under argon matrix condition as a function of the sublimation temperature revealed significant changes in the intensity of the $v(\mathrm{C}=\mathrm{O})$ and $v\left(\mathrm{NO}_{2}\right)$ stretching vibration bands (Figure 14). The result was used to attribute particular bands to two isomers of the compound.

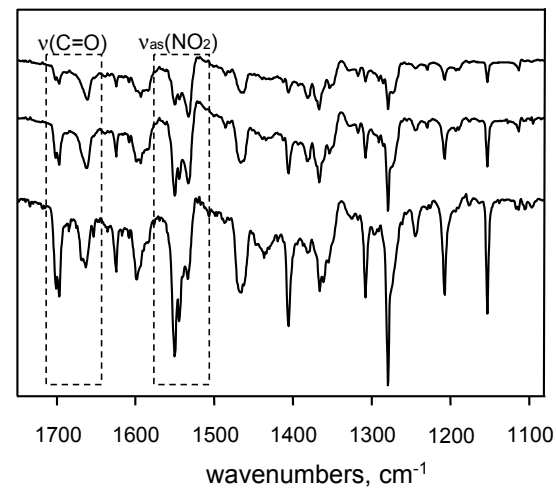

Figure 14. Spectrum of 5-methyl-3-nitro-2-hydroxyacetophenone (11) in argon matrix condition in the function of sublimation. Reprinted with permission from [91]. Copyright 2008 Elsevier.

\subsection{Ortho-Hydroxyaryl Amides (3)}

An amide bond in proteins plays an essential role in the functioning of every living organism, therefore, the description of the conformation of such systems is very important. Papers [94,111] showed the importance of complex studies of ortho-hydroxyaryl amides. The ${ }^{1} \mathrm{H}$ and ${ }^{13} \mathrm{C}-\mathrm{NMR}$ spectra of ortho-hydroxyaryl amides studied as a function of temperature demonstrate the presence of a dynamic effect evoked by the non-equivalent orientation of dimethylamine, diethylamine, morpholine and pyrrolidine groups $[94,111]$.

The infrared spectra (Figure 15) recorded as a function of temperature in weakly-polar, protondonating and proton-accepting solvents indicate the existence of equilibrium between intramolecular and intermolecular hydrogen bonds [94]. It should be underlined that an easy disruption of a rather strong intramolecular hydrogen bond observed in 2-hydroxy- $N$-methylbenzamide [112], salicylamide [113] and 4-chloro-2-hydroxybenzamide [114] $(\mathrm{d}(\mathrm{OO})=2.53-2.47 \AA)$ is an outcome of a steric effect of the ethyl groups in 2-hydroxy- $N, N$-dialkylbenzamides and a weakened conjugation between the phenyl and amide moieties due to competitive resonance [94,111]. Further investigations of infrared spectra revealed the shift of the $v(\mathrm{C}=\mathrm{O})$ bands depending on the solvent polarity (Figure 15). In the case of proton-accepting solvent, we observe the disruption of intramolecular hydrogen bonding and the formation of the complex with the solvent molecules, which shifts the $v(\mathrm{C}=\mathrm{O})$ band towards higher wavenumbers with respect to that in weakly-polar solvent. This fact is explained by the disruption of hydrogen bonding (Figure 16) and the strengthening of the force constant of this bond. The shift of the $v(\mathrm{C}=\mathrm{O})$ band in the case of the amphoteric solvent is drastically different (the shift towards lower wavenumbers) from the proton-acceptor solvent. Such effect is conditioned by the formation of intermolecular hydrogen bonding between the carbonyl group and the solvent molecules, which weakens the carbonyl bond and decreases force constant. 

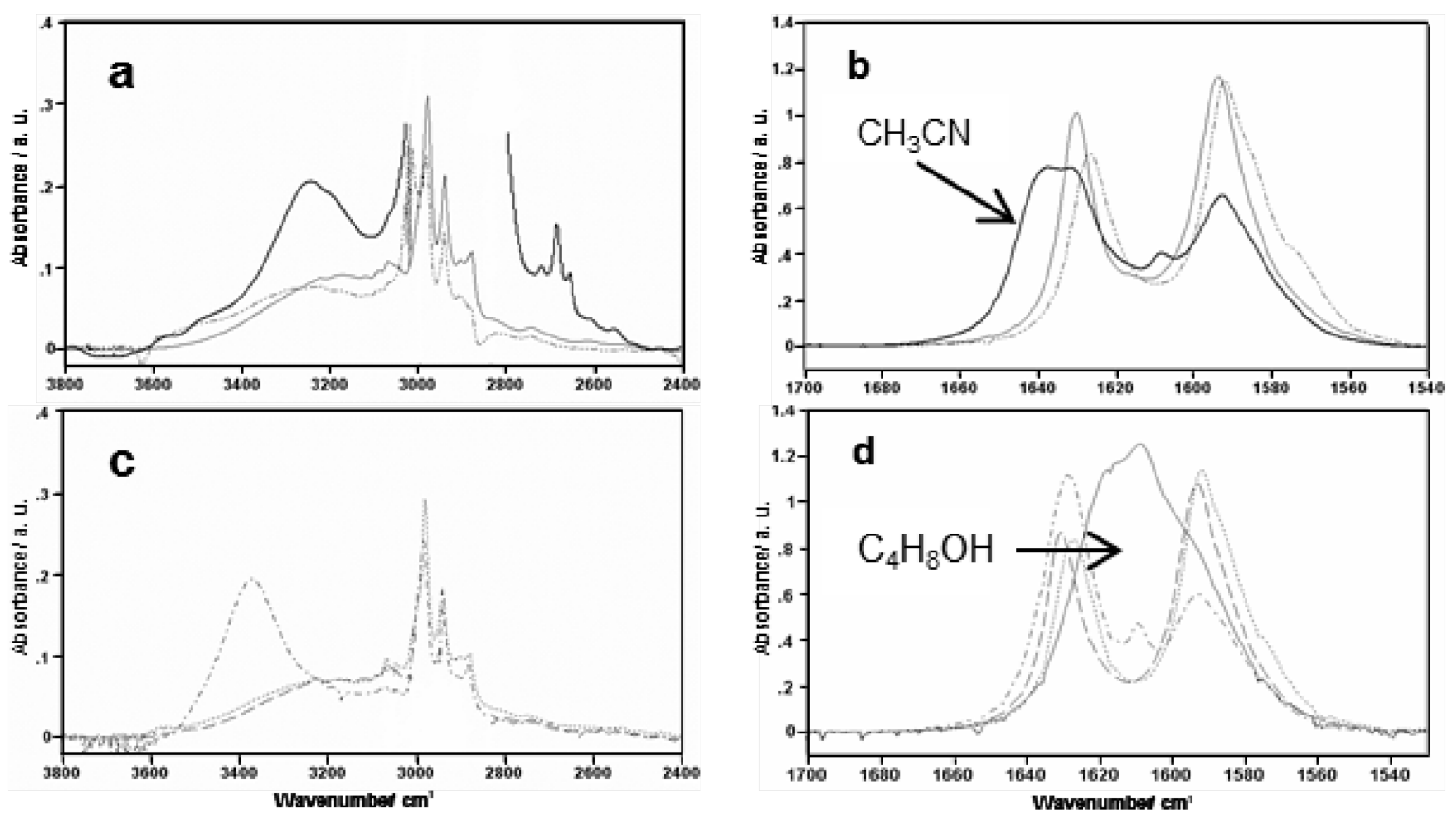

Figure 15. Infrared spectra of 2-hydroxy- $N$, $N$-diethylbenzamide $\left(3, \mathrm{R}_{1}=\mathrm{R}_{2}=\mathrm{C}_{2} \mathrm{H}_{5}\right.$; Figure 1$)$ in the region of the $v(\mathrm{OH})$ (left side) and $v(\mathrm{C}=\mathrm{O})$ (right side) modes for 2-hydroxy- $N, N$-diethylbenzamide: (a,b) solid line $-\mathrm{CCl}_{4},$. line $-\mathrm{CHCl}_{3}$, bold line $-\mathrm{C}_{4} \mathrm{H}_{8} \mathrm{O}$; (c) - . - line $-\mathrm{C}_{4} \mathrm{H}_{9} \mathrm{Cl}$,.. line $-\mathrm{CH}_{2} \mathrm{Cl}_{2}$, -.-.- line- $\mathrm{CH}_{3} \mathrm{CN}$; (d) - - - line $-\mathrm{C}_{4} \mathrm{H}_{9} \mathrm{Cl}$, .. line $-\mathrm{CH}_{2} \mathrm{Cl}_{2}$, -...- line $-\mathrm{CH}_{3} \mathrm{CN}$, solid line $-\mathrm{C}_{4} \mathrm{H}_{9} \mathrm{OH}$. Reprinted with permission from [94]. Copyright 2008 John Wiley \& Sons, Ltd.<smiles>[R]N([R2])C(=O)c1ccccc1O[CH][n+]1ccccc1</smiles>

(a)<smiles></smiles>

(b)

Figure 16. Complexes of 2-hydroxy- $N, N$-diethylbenzamide $\left(3, \mathrm{R}_{1}=\mathrm{R}_{2}=\mathrm{C}_{2} \mathrm{H}_{5}\right.$; Figure 1) with pyridine (a) and alcohol (b) $(\mathrm{R}=$ alkyl group). Reprinted with permission from [94]. Copyright 2008 John Wiley \& Sons, Ltd.

The measurements of an average molecular mass (Figure 17) also exhibit ambiguous influence of amphoteric and proton-acceptor solvents. These results point out the presence of self-association but only in proton-accepting solvents. Different behaviour of a compound in amphoteric and proton-accepting solvents is due to the blocking of a basic center of the molecule, which prevents the formation of the complex (Figure 16). This hypothesis is supported by the results obtained from the infrared measurements. 


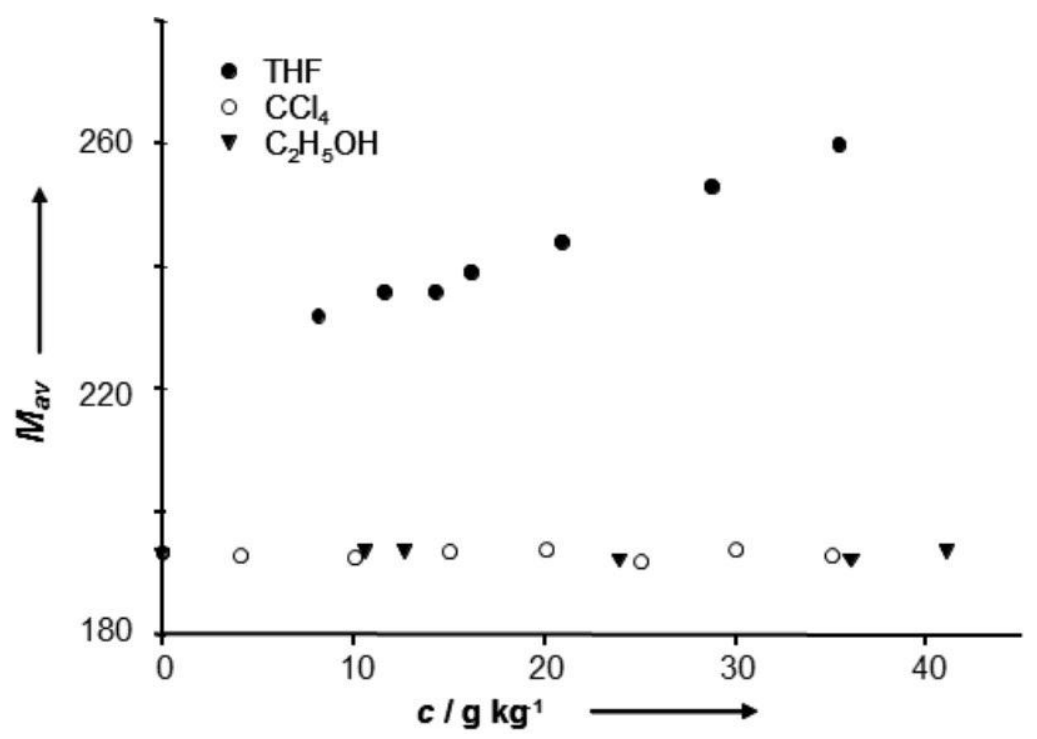

Figure 17. Dependence of average molecular weight $\left(\mathrm{M}_{\mathrm{av}}\right)$ on concentration. Reprinted with permission from [94]. Copyright 2008 John Wiley \& Sons, Ltd.

\section{Short Summary}

Hydrogen bonding is one of the main concepts in contemporary chemistry [63,95,104,108,115-127] and its study is important for the development of the discipline. Intramolecular hydrogen bonds in ortho-hydroxyaryl Schiff and Mannich bases, in ortho-hydroxyaryl ketones and amides, in proton sponges and related compounds could be considered as classical objects for the investigation. Though the presented short review does not cover the topic in its entirety, we have tried to outline the main current research directions. On the one hand, the geometric and spectroscopic characteristics of the abovementioned intramolecular hydrogen bonds are typical for H-bonds of medium strength (for an $\mathrm{XHY}$ bond it is short $\mathrm{XY}$ contact, $\mathrm{XH}$ elongation, ordinary directionality pattern, $v(\mathrm{XH})$ frequency decrease, bridging proton deshielding etc.). On the other hand, there are enough specific properties, which make the study of such bonds a topic in its own right. Perhaps the most prominent feature is a possibility of proton delocalization due to the prototropic equilibrium between molecular and zwitterionic forms, possible in some systems. The tautomeric equilibrium is temperature-, solventand substituent dependent; it is also strongly influenced by additional intermolecular hydrogen bonds formed by the molecule (with or without breaking the intramolecular bond). Other sources of proton delocalization are the formation of stronger intramolecular hydrogen bonds with broader proton potentials and thermally fluctuating medium effect, which are influencing $\mathrm{H}$-bond geometry. The equilibrium constant of the tautomeric equilibrium changes together with the intrinsic geometric and spectroscopic properties of individual tautomers, which complicates the analysis of the experimental data. Here, quantum-chemical computations are often providing the necessary insight via adiabatic and non-adiabatic PES calculations. Another interesting feature of intramolecular H-bond discussed in this short review is the stabilization provided by the $\pi$-electron delocalization in the chelate chain, which gives the name Resonance-Assisted Hydrogen Bonds (RAHB).

Acknowledgments: This work was supported by KNOW-9 grant and project Nr 47 from 22.01.2016, p. 17. The authors gratefully acknowledge the Wroclaw Centre for Networking and Supercomputing (WCSS) for computational facilities. This work were prepared within the framework of RFBR grants: 14-03-00716 and 16-03-00405.

Conflicts of Interest: The authors declare no conflict of interest. 


\section{References}

1. Cleland, W.W.; Kreevoy, M.M. Low-barrier hydrogen-bonds and enzymatic catalysis. Science 1994, 264, 1887-1890. [CrossRef] [PubMed]

2. Hur, O.; Leja, C.; Dunn, M. Evidence of a low-barrier hydrogen bond in the tryptophan synthase catalytic mechanism. Biochemistry 1996, 35, 7378-7386. [CrossRef] [PubMed]

3. Cleland, W.W.; Frey, P.A.; Gerlt, J.A. The low barrier hydrogen bond in enzymatic catalysis. J. Biol. Chem. 1998, 273, 25529-25532. [CrossRef] [PubMed]

4. Przybylski, P.; Huczynski, A.; Pyta, K.; Brzeziński, B.; Bartl, F. Biological properties of Schiff bases and azo derivatives of phenols. Curr. Org. Chem. 2009, 13, 124-148. [CrossRef]

5. Ritter, E.; Przybylski, P.; Brzeziński, B.; Bartl, F. Schiff bases in biological systems. Curr. Org. Chem. 2009, 13, 241-249. [CrossRef]

6. Napier, I.; Ponka, P.; Richardson, D.R. Iron trafficking in the mitochondrion: Novel pathways revealed by disease. Blood 2005, 105, 1867-1874. [CrossRef] [PubMed]

7. Gou, Y.; Wang, J.; Chen, S.; Zhang, Z.; Zhang, Y.; Zhang, W.; Yang, F. $\alpha-N$-heterocyclic thiosemicarbazone Fe(III) complex: Characterization of its antitumor activity and identification of anticancer mechanism. Eur. J. Med. Chem. 2016, 123, 354-364. [CrossRef] [PubMed]

8. Boese, A.D.; Martin, J.M.L.; Klopper, W. Basis Set Limit Coupled Cluster Study of H-Bonded Systems and Assessment of More Approximate Methods. J. Phys. Chem. A 2007, 111, 11122-11133. [CrossRef] [PubMed]

9. Boese, A.D. Density Functional Theory and Hydrogen Bonds: Are We There Yet? ChemPhysChem 2015, 16, 978-985. [CrossRef] [PubMed]

10. Tomasi, J.; Mennucci, B.; Cammi, R. Quantum mechanical continuum solvation models. Chem. Rev. 2005, 105, 2999-3093. [CrossRef] [PubMed]

11. Filarowski, A.; Koll, A.; Hansen, P.E.; Kluba, M. Density functional theory study of intramolecular hydrogen bonding and proton transfer in o-hydroxyaryl ketimines. J. Phys. Chem. 2008, 112, 3478-3485. [CrossRef] [PubMed]

12. Filarowski, A.; Majerz, I. AIM analysis of intramolecular hydrogen bonding in $o$-hydroxy aryl Schiff bases. J. Phys. Chem. 2008, 112, 3119-3126. [CrossRef] [PubMed]

13. Panek, J.; Filarowski, A.; Jezierska-Mazzarello, A. Impact of proton transfer phenomena on the electronic structure of model Schiff bases: An AIM/NBO/ELF study. J. Chem. Phys. 2013, 139, 154312. [CrossRef] [PubMed]

14. Martyniak, A.; Panek, J.J.; Jezierska-Mazzarello, A.; Filarowski, A. Triple hydrogen bonding in a circular arrangement: ab initio, DFT and first-principles MD studies of tris-hydroxyaryl enamines. J. Comput. Aided Mol. Des. 2012, 9, 1045-1053. [CrossRef] [PubMed]

15. Martyniak, A.; Majerz, I.; Filarowski, A. Peculiarities of quasi-aromatic hydrogen bonding. RSC Adv. 2012, 2, 8135-8144. [CrossRef]

16. Jański, J.; Koll, A. Solvent and Substitution Influence on the Character of Tautomers Resulting from Proton Transfer Reaction in Some Phenol Derivatives. Struct. Chem. 2004, 15, 353-361. [CrossRef]

17. Mata, I.; Alkorta, I.; Espinosa, E.; Molins, E. Relationships between interaction energy, intermolecular distance and electron density properties in hydrogen bonded complexes under external electric fields. Chem. Phys. Lett. 2011, 507, 185-189. [CrossRef]

18. Vener, M.V.; Manaev, A.V.; Egorova, A.N.; Tsirelson, V.G. QTAIM study of strong H-bonds with the O-H center dot center dot center dot A fragment $(\mathrm{A}=\mathrm{O}, \mathrm{N})$ in three-dimensional periodical crystals. J. Phys. Chem. A 2007, 111, 1155-1162. [CrossRef] [PubMed]

19. Grabowski, S.J.; Sokalski, W.A.; Leszczynski, J. The possible covalent nature of N-H center dot center dot center dot $\mathrm{O}$ hydrogen bonds in formamide dimer and related systems: An ab initio study. J. Phys. Chem. A 2006, 110, 4772-4779. [CrossRef] [PubMed]

20. Grabowski, S.J.; Leszczyński, J. Hydrogen Bonding-New Insights; Grabowski, S.J., Ed.; Springer: Berlin, Germany, 2006.

21. Grabowski, S.J.; Sokalski, W.A.; Dyguta, E.; Leszczynski, J. Quantitative classification of covalent and noncovalent H-bonds. J. Phys. Chem. B 2006, 110, 6444-6446. [CrossRef] [PubMed]

22. Basilevsky, M.V.; Vener, M.V. Theoretical investigations of proton and hydrogen atom transfer in the condensed phase. Russ. Chem. Rev. 2003, 72, 3-39. [CrossRef] 
23. Rybarczyk-Pirek, A.J.; Grabowski, S.J.; Małecka, M.; Nawrot-Mordanka, J. Crystal and molecular structures of new chromone derivatives as empirical evidence of intramolecular proton transfer reaction; ab initio studies on intramolecular H-bonds in enaminones. J. Phys. Chem. 2002, 106, 11956-11962. [CrossRef]

24. Musin, R.N.; Mariam, Y.H. An integrated approach to the study of intramolecular hydrogen bonds in malonaldehyde enol derivatives and naphthazarin: Trend in energetic versus geometrical consequences. J. Phys. Org. Chem. 2006, 19, 425-444. [CrossRef]

25. Weinhold, F.; Klein, R.A. What is a hydrogen bond? Mutually consistent theoretical and experimental criteria for characterizing H-bonding interactions. Mol. Phys. 2012, 110, 565-579. [CrossRef]

26. Arunan, E.; Desiraju, G.R.; Klein, R.A.; Sadlej, J.; Scheiner, S.; Alkorta, I.; Clary, D.C.; Crabtree, R.H.; Dannenberg, J.J.; Hobza, P.; et al. Definition of the hydrogen bond (IUPAC Recommendations 2011). Pure Appl. Chem. 2011, 83, 1637-1641. [CrossRef]

27. Badger, R.M.; Bauer, S.H. Spectroscopic Studies of the Hydrogen Bond. II. The Shift of the OH Vibrational Frequency in the Formation of the Hydrogen Bond. J. Chem. Phys. 1937, 5, 839-851. [CrossRef]

28. Szafran, M. Recent aspects of the proton transfer reaction in H-bonded complexes. J. Mol. Struct. 1996, 381, 39-64. [CrossRef]

29. Drago, R.S.; Epley, T.D. Enthalpies of hydrogen bonding and changes in hydroxy frequency shifts for a series of adducts with substituted phenols. J. Am. Chem. Soc. 1969, 91, 2883-2890. [CrossRef]

30. Hadži, D.; Bratos, S. Vibrational spectroscopy of the hydrogen bond. In The Hydrogen Bond. Recent Developments in Theory and Experiments; Schuster, P., Zundel, G., Sandorfy, C., Eds.; North-Holland: Amsterdam, The Netherlands, 1976.

31. Iogansen, A.V. Direct proportionality of the hydrogen bonding energy and the intensification of the stretching $v(\mathrm{XH})$ vibration in infrared spectra. Spectrochim. Acta A 1999, 55, 1585-1612. [CrossRef]

32. Banerjee, P.; Mukhopadhyay, D.P.; Chakraborty, T. On the origin of donor O-H bond weakening in phenol-water complexes. J. Chem. Phys. 2015, 143, 204306. [CrossRef] [PubMed]

33. Ishikawa, R.; Kojima, C.; Ono, A.; Kainosho, M. Developing model systems for the NMR study of substituent effects on the N-H center dot center dot center dot $\mathrm{N}$ hydrogen bond in duplex DNA. Magn. Res. Chem. 2001, 39, S159-S165. [CrossRef]

34. Libowitzky, E. Correlation of O-H Stretching Frequencies and O-H …O Hydrogen Bond Lengths in Minerals. Monatsh. Chem. 1999, 130, 1047-1059.

35. Lautié, A.; Froment, F.; Novak, A. Relationship Between NH Stretching Frequencies and N...O Distances of Crystals Containing NH...O Hydrogen Bonds. Spectrosc. Lett. 1976, 9, 289-299. [CrossRef]

36. Limbach, H.-H.; Tolstoy, P.M.; Perez-Hernandez, N.; Guo, J.; Shenderovich, I.G.; Denisov, G.S. OHO Hydrogen Bond Geometries and NMR Chemical Shifts: From Equilibrium Structures to Geometric H/D Isotope Effects, with Applications for Water, Protonated Water, and Compressed Ice. Israel J. Chem. 2009, 49, 199-216. [CrossRef]

37. Grzegorzek, J.; Filarowski, A.; Mielke, Z. The photoinduced isomerization and its implication in the photo-dynamical processes in two simple Schiff bases isolated in solid argon. Phys. Chem. Chem. Phys. 2011, 13, 16596-16605. [CrossRef] [PubMed]

38. Majerz, I.; Pawlukojć, A.; Sobczyk, L.; Dziembowska, T.; Grech, E.; Szady-Chełmieniecka, A. The infrared, Raman and inelastic neutron scattering studies on 5-nitro-N-salicylideneethylamine. J. Mol. Struct. 2000, 552, 243-247. [CrossRef]

39. Filarowski, A.; Koll, A.; Lipkowski, P.; Pawlukojć, A. Inelastic neutron scattering and vibrational spectra of 2-(N-methyl- $\alpha$-iminoethyl)-phenol and 2-(N-methyliminoethyl)-phenol. Experimental and theoretical approach. J. Mol. Struct. 2008, 880, 97-108. [CrossRef]

40. Filarowski, A.; Koll, A. Integrated intensity of $v_{\mathrm{s}}(\mathrm{OH})$ absorption bands in bent hydrogen bonds in ortho-dialkylaminomethyl phenols. Vib. Spectrosc. 1996, 12, 15-24. [CrossRef]

41. Berkesi, O.; Körtvélyesi, T.; Hetényi, C.; Németh, T.; Pálinkó, I. Hydrogen bonding interactions of benzylidene type Schiff bases studied by vibrational spectroscopic and computational methods. Phys. Chem. Chem. Phys. 2003, 5, 2009-2014. [CrossRef]

42. Król-Starzomska, I.; Filarowski, A.; Rospenk, M.; Koll, A.; Melikova, S.M. Proton transfer equilibria in Schiff bases with steric repulsion. J. Phys. Chem. A 2004, 108, 2131-2138. [CrossRef]

43. Majerz, I.; Dziembowska, T.; Ambroziak, K. Analysis of the vibrational spectra of trans- $N, N^{\prime}$-bis-Rsalicylidene-1', 2'-cyclohexanediamine. J. Mol. Struct. 2007, 828, 166-173. [CrossRef]

44. Filarowski, A.; Koll, A.; Sobczyk, L. Vibrational spectra of $o$-hydroxyphenyl Schiff bases and related compounds. Curr. Org. Chem. 2009, 13, 287-298. [CrossRef] 
45. Kurkovskaya, L.N.; Nurmukhamedov, R.N.; Shigorin, D.N. Proof of the bipolar structure of the NH-tautomer of $\mathrm{H}$-chelate rings of the aromatic series by ${ }^{1} \mathrm{H}$ and ${ }^{13} \mathrm{C}-\mathrm{NMR}$. J. Struct. Chem. 1980, 21, 612-620. [CrossRef]

46. Sharif, S.; Denisov, G.S.; Toney, M.D.; Limbach, H.H. NMR studies of solvent-assisted proton transfer in a biologically relevant Schiff base: Towards a distinction of geometric and equilibrium H-bond isotope effects. J. Am. Chem. Soc. 2006, 128, 3375-3387. [CrossRef] [PubMed]

47. Filarowski, A.; Koll, A.; Rospenk, M.; Król-Starzomska, I.; Hansen, P.E. Tautomerism of sterically hindered Schiff bases. Deuterium isotope effects on ${ }^{13} \mathrm{C}$ chemical shifts. J. Phys. Chem. A 2005, 109, 4464-4473. [CrossRef] [PubMed]

48. Koeppe, B.; Tolstoy, P.M.; Limbach, H.H. Reaction Pathways of Proton Transfer in Hydrogen bonded Phenol-Carboxylate Complexes explored by UVNMR. J. Am. Chem. Soc. 2011, 133, 7897-7908. [CrossRef] [PubMed]

49. Koeppe, B.; Guo, J.; Tolstoy, P.M.; Denisov, G.S.; Limbach, H.H. Solvent and H/D Isotope Effects on the Proton Transfer Pathways in Heteroconjugated Hydrogen-Bonded Phenol-Carboxylic Acid Anions Observed by Combined UV-vis and NMR Spectroscopy. J. Am. Chem. Soc. 2013, 135, 7553-7566. [CrossRef] [PubMed]

50. Pylaeva, S.; Allolio, C.; Koeppe, B.; Denisov, G.S.; Limbach, H.H.; Sebastiani, D.; Tolstoy, P.M. Proton transfer in a short hydrogen bonded complex caused by solvation shell fluctuations: An ab initio MD and NMR/UV study of an (OHO)-bonded system. Phys. Chem. Chem. Phys. 2015, 17, 4634-4644. [CrossRef] [PubMed]

51. Golubev, N.S.; Smirnov, S.N.; Tolstoy, P.M.; Sharif, S.; Toney, M.D.; Denisov, G.S.; Limbach, H.H. Observation by NMR of the tautomerism of an intramolecular $\mathrm{OHOHN}$-charge relay chain in a model Schiff base. J. Mol. Struct. 2007, 844-845, 319-327. [CrossRef]

52. Limbach, H.H.; Chan-Huot, M.; Sharif, S.; Tolstoy, P.M.; Shenderovich, I.G.; Denisov, G.S.; Toney, M.D. Critical hydrogen bonds and protonation states of pyridoxal 5'-phosphate revealed by NMR. Biochim. Biophys. Acta Proteins Proteom. 2011, 1814, 1426-1437. [CrossRef] [PubMed]

53. Chan-Huot, M.; Sharif, S.; Tolstoy, P.M.; Toney, M.D.; Limbach, H.H. NMR studies of the Stability, Protonation States and Tautomerism of ${ }^{13} \mathrm{C}$ and ${ }^{15} \mathrm{~N}$ Labeled Aldimines of the Coenzyme Pyridoxal 5'-phosphate in Water. Biochemistry 2010, 49, 10818-10830. [CrossRef] [PubMed]

54. Chan-Huot, M.; Niether, C.; Sharif, S.; Tolstoy, P.M.; Toney, M.D.; Limbach, H.H. NMR Studies of the Protonation States of Pyridoxal 5'-phosphate in Water. J. Mol. Struct. 2010, 976, 282-289. [CrossRef]

55. Sharif, S.; Denisov, G.S.; Toney, M.D.; Limbach, H.H. NMR studies of coupled low- and high-barrier hydrogen bonds in pyridoxal-5'-phosphate model systems in polar solution. J. Am. Chem. Soc. 2007, 129, 6313-6327. [CrossRef] [PubMed]

56. Sharif, S.; Powell, D.R.; Schagen, D.; Steiner, T.M.; Toney, M.D.; Fogle, E.; Limbach, H.H. X-ray crystallographic structures of enamine and amine Schiff bases of pyridoxal and its 1:1 hydrogen bonded complexes with benzoic acid derivatives: Evidence for coupled inter- and intramolecular proton transfer. Acta Crystallogr. B 2008, 62, 480-487. [CrossRef] [PubMed]

57. Sharif, S.; Schagen, D.; Toney, M.D.; Limbach, H.H. Coupling of functional hydrogen bonds in pyridoxal-5' phosphate-enzyme model systems observed by solid state NMR spectroscopy. J. Am. Chem. Soc. 2007, 129, 4440-4455. [CrossRef] [PubMed]

58. Sharif, S.; Fogle, E.; Toney, M.D.; Denisov, G.S.; Shenderovich, I.G.; Tolstoy, P.M.; Chan-Huot, M.; Buntkowsky, G.; Limbach, H.H. NMR localization of protons in critical enzyme hydrogen bonds. J. Am. Chem. Soc. 2007, 129, 9558-9559. [CrossRef] [PubMed]

59. Chan-Huot, M.; Dos, A.; Zander, R.; Sharif, S.; Tolstoy, P.M.; Compton, S.; Fogle, E.; Toney, M.D.; Shenderovich, I.G.; Denisov, G.S.; et al. NMR studies of protonation and hydrogen bond states of internal aldimines of pyridoxal 5'-phosphate acid-base in alanine racemase, aspartate aminotransferase and poly-L-lysine. J. Am. Chem. Soc. 2013, 135, 18160-18175. [CrossRef] [PubMed]

60. Hansen, P.E.; Bolvig, S. Deuterium Isotope Effects on ${ }^{13} \mathrm{C}$ Chemical Shifts of $o$-Hydroxyacyl Aromatics. Intramolecular Hydrogen Bonding. Magn. Res. Chem. 1997, 35, 520-528. [CrossRef]

61. Filarowski, A.; Koll, A.; Kochel, A.; Kalenik, J.; Hansen, P.E. The intramolecular hydrogen bond in ortho-hydroxy acetophenones. J. Mol. Struct. 2004, 700, 67-72. [CrossRef]

62. Filarowski, A.; Kochel, A.; Hansen, P.E.; Urbanowicz, A.; Szymborska, K. The role of ring substituents on hydrogen bonding of 5-cyano-2-hydroxyacetophenone and 2-hydroxy-4-methoxy-5-nitroacetophenone in the ground and excited states. J. Mol. Struct. 2007, 844, 77-82. [CrossRef] 
63. Han, K.-L.; Zhao, G.-J. (Eds.) Hydrogen Bonding and Transfer in the Excited State; John Wiley \& Sons, Ltd.: Chichester, UK, 2011.

64. Wu, K.-C.; Cheng, Y.-M.; Lin, Y.-S.; Yeh, Y.-S.; Pu, S.-C.; Hu, Y.-H.; Yu, J.-K.; Che, P.-T. Competitive intramolecular hydrogen bonding formation and excited-state proton transfer reaction in 1-[(diethylamino)-methyl]-2hydroxy-3-naphthaldehyde. Chem. Phys. Lett. 2004, 384, 203-209. [CrossRef]

65. Daengngern, R.; Prommin, C.; Rungrotmongkol, T.; Promarak, V.; Wolschann, P.; Kungwan, N. Theoretical investigation of 2-(iminomethyl)phenol in the gas phase as a prototype of ultrafast excited-state intramolecular proton transfer. Chem. Phys. Lett. 2016, 657, 113-118. [CrossRef]

66. Jezierska, A.; Panek, J.; Filarowski, A. Molecular properties investigation of a substituted aromatic Mannich base: Dynamic and static models. J. Chem. Inf. Model. 2007, 47, 818-831. [CrossRef] [PubMed]

67. Filarowski, A.; Szemik-Hojniak, A.; Głowiak, T.; Koll, A. Anomalous strengthening of the intramolecular hydrogen bond by steric repulsion. J. Mol. Struct. 1997, 404, 67-74. [CrossRef]

68. Marx, D.; Hutter, J. Ab Initio Molecular Dynamics: Basic Theory and Advanced Methods; Cambridge University Press: Cambridge, UK, 2009.

69. Jezierska-Mazzarello, A.; Panek, J.J.; Vuilleumier, R.; Koll, A.; Ciccotti, G. Direct observation of the substitution effects on the hydrogen bridge dynamics in selected Schiff bases-A comparative molecular dynamics study. J. Chem. Phys. 2011, 134, 034308. [CrossRef] [PubMed]

70. Durlak, P.; Berski, S.; Latajka, Z. Car-Parrinello and path integral molecular dynamics study of the hydrogen bond in the acetic acid dimer in the gas phase. J. Mol. Model. 2011, 17, 2995-3004. [CrossRef] [PubMed]

71. Denisov, G.S.; Gindin, V.A.; Golubev, N.S.; Koltsov, A.I.; Smirnov, S.N.; Rospenk, M.; Koll, A.; Sobczyk, L. Pyramidal nitrogen inversion hindered by a strong intramolecular hydrogen bond in 2-diethylaminomethyl phenols. Magn. Reson. Chem. 1993, 31, 1034-1037. [CrossRef]

72. Sitkowski, J.; Stefaniak, L.; Rospenk, M.; Sobczyk, L.; Webb, G.A. Multinuclear, variable-temperature NMR study of hydrogen bonding in two ortho-Mannich bases. J. Phys. Org. Chem. 1995, 8, 463-467. [CrossRef]

73. Rospenk, M.; Sobczyk, L. ${ }^{1}$ H-NMR studies of proton transfer in ortho-Mannich bases. Magn. Reson. Chem. 1989, 27, 445-450. [CrossRef]

74. Rospenk, M.; Sobczyk, L.; Schah-Mohammedi, P.; Limbach, H.H.; Golubev, N.S.; Melikova, S.M. Dimerization and solvent assisted proton dislocation in the low-barrier hydrogen bond of a Mannich base. A low-temperature NMR study. Magn. Reson. Chem. 2001, 39, S81-S90. [CrossRef]

75. Rospenk, M.; Koll, A.; Sobczyk, L. Proton transfer and secondary deuterium isotope effect in the ${ }^{13} \mathrm{C}-\mathrm{NMR}$ spectra of ortho-aminomethyl phenols. Chem. Phys. Lett. 1996, 261, 283-288. [CrossRef]

76. Degtyarev, A.V.; Ryabtsova, O.V.; Pozharskii, A.F.; Ozeryanskii, V.A.; Starikova, Z.A.; Sobczyk, L.; Filarowski, A. 2,7-Disubstituted proton sponges as borderline systems for investigating barrier-free intramolecular hydrogen bonds. Protonated 2,7-bis(dimethylsilyl)- and 2,7-di(hydroxymethyl)-1,8-bis(dimethylamino)naphthalenes. Tetrahedron 2008, 64, 6209-6214. [CrossRef]

77. Pozharskii, A.F.; Degtyarev, A.V.; Ryabtsova, O.V.; Ozeryanskii, V.A.; Kletskii, M.E.; Starikova, Z.A.; Sobczyk, L.; Filarowski, A. 2-alpha-hydroxyalkyl- and 2,7-di(alpha-hydroxyalkyl)-1,8-bis(dimethylamino)naphthalenes: Stabilization of nonconventional in/out conformers of "proton sponges" via N..H-O intramolecular hydrogen bonding. A remarkable kind of tandem nitrogen inversion. J. Org. Chem. 2007, 72, 3006-3019. [CrossRef] [PubMed]

78. Ozeryanskii, V.A.; Pozharskii, A.F.; Bienko, A.J.; Sawka-Dobrowolska, W.; Sobczyk, L. [NHN]+ Hydrogen Bonding in Protonated 1,8-Bis(dimethylamino)-2,7-dimethoxynaphthalene. X-ray Diffraction, Infrared, and Theoretical ab Initio and DFT Studies. J. Phys. Chem. A 2005, 109, 1637-1642. [CrossRef] [PubMed]

79. Bieńko, A.J.; Latajka, Z.; Sawka-Dobrowolska, W.; Sobczyk, L.; Ozeryanskii, V.A.; Pozharskii, A.F.; Grech, E.; Nowicka-Scheibe, J. Low barrier hydrogen bond in protonated proton sponge. X-ray diffraction, infrared, and theoretical ab initio and density functional theory studies. J. Chem. Phys. 2003, 119, 4313-4319. [CrossRef]

80. Majerz, I.; Olovsson, I. Proton transfer in the intramolecular NHN+ bonds in proton sponges with different hydrogen bridge flexibility. Phys. Chem. Chem. Phys. 2009, 11, 1297-1302. [CrossRef] [PubMed]

81. Perrin, C.L.; Nielson, J.B. "Strong" hydrogen bonds in chemistry and biology. Ann. Rev. Phys. Chem. 1997, 48, 511-544. [CrossRef] [PubMed]

82. Pozharskii, A.; Ozeryanskii, V.A. Proton sponges. In The Chemistry of Anilines; Rappoport, Z., Ed.; John Wiley \& Sons, Ltd.: Chichester, UK, 2007. 
83. Growiak, T.; Majerz, I.; Malarski, Z.; Sobczyk, L.; Pozharskii, A.F.; Ozeryanskii, V.A.; Grech, V.A. Structure and IR spectroscopic behaviour of 2,7-dichloro-1,8-bis(dimethylamino)naphthalene and its protonated form. J. Phys. Org. Chem. 1999, 12, 895-900.

84. Pietrzak, M.; Try, A.; Andrioletti, B.; Sessler, J.; Anzenbacher, P.; Limbach, H.H. The largest ${ }^{15} \mathrm{~N} \ldots{ }^{15} \mathrm{~N}$ coupling constant across an NHN-hydrogen bond. Angew. Chem. Int. Ed. 2008, 47, 1123-1126. [CrossRef] [PubMed]

85. Pietrzak, M.; Wehling, J.; Limbach, H.H.; Golubev, N.S.; López, C.; Claramunt, R.M.; Elguero, J. ${ }^{13}$ C detected Scalar Nitrogen-Nitrogen Couplings across the Intramolecular Symmetric NHN-Hydrogen Bond of Proton Sponge. J. Am. Chem. Soc. 2001, 123, 4338-4339. [CrossRef] [PubMed]

86. Pietrzak, M.; Wehling, J.P.; Kong, S.; Tolstoy, P.M.; Shenderovich, I.G.; López, C.; Claramunt, R.M.; Elguero, J.; Denisov, G.S.; Limbach, H.H. Symmetrization of Cationic Hydrogen Bridges of Protonated Sponges Induced by Solvent and Counteranion Interactions as Revealed by NMR Spectroscopy. Chem. Eur. J. 2010, 16, 1679-1690. [CrossRef] [PubMed]

87. López, C.; Lorente, P.; Claramunt, R.M.; Marín, J.; Foces-Foces, C.; Llamas-Saiz, A.L.; Elguero, J.; Limbach, H.H. Localization of Hydrogen Bond Deuterons in Proton Sponges by Dipolar Solid State ${ }^{15} \mathrm{~N}-\mathrm{NMR}$ Spectroscopy. Special Issue on Hydrogen Transfer: Experiment and Theory. Ber. Bunsenges. Phys. 1998, 102, 414-418. [CrossRef]

88. Lesnichin, S.B.; Tolstoy, P.M.; Limbach, H.H.; Shenderovich, I.G. Counteranion-dependent intra- vs. intermolecular hydrogen bonding and proton transfer of $2,2^{\prime}$-bipyridinium in $\mathrm{CDF}_{3} / \mathrm{CDF}_{2} \mathrm{Cl}$ observed by low-temperature NMR. Phys. Chem. Chem. Phys. 2010, 12, 10373-10379. [CrossRef] [PubMed]

89. Gurinov, A.A.; Lesnichin, S.B.; Limbach, H.H.; Shenderovich, I.G. How short is the strongest hydrogen bond in the proton-bound homodimers of pyridine derivatives? J. Phys. Chem. A 2014, 118, 10804-10812. [CrossRef] [PubMed]

90. Filarowski, A.; Koll, A.; Sobczyk, L. Intramolecular Hydrogen Bonding in o-hydroxy Aryl Schiff Bases. Curr. Org. Chem. 2009, 13, 172-193. [CrossRef]

91. Pająk, A.; Maes, G.; De Borggraeve, W.M.; Boens, N.; Filarowski, A. Matrix-Isolation FT-IR and Theoretical investigation of the competitive hydrogen bonding in 5-methyl-3-nitro-2-hydroxyacetophenone. J. Mol. Struct. 2008, 880, 86-96. [CrossRef]

92. Markle, T.F.; Tenderholt, A.F.; Mayer, J.M. Probing Quantum and Dynamic Effects in Concerted Proton-Electron Transfer Reactions of Phenol-Base Compounds. J. Phys. Chem. B 2012, 116, 571-584. [CrossRef] [PubMed]

93. Jezierska, A.; Panek, J.; Koll, A.; Mavri, J. Car-Parrinello simulation of an O-H stretching envelope and potential of mean force of an intramolecular hydrogen bonded system: Application to a Mannich base in solid state and in vacuum. J. Chem. Phys. 2007, 126, 205101. [CrossRef] [PubMed]

94. Majewska, P.; Pająk, J.; Rospenk, M.; Filarowski, A. The intra- versus intermolecular hydrogen bonding equilibrium in 2-hydroxy-N,N-diethylbenzamide. J. Phys. Org. Chem. 2008, 22, 130-137. [CrossRef]

95. Gilli, G.; Gilli, P. The Nature of the Hydrogen Bond. Outline of a Comprehensive Hydrogen Bond Theory; Oxford University Press: Oxford, UK, 2009.

96. Lutskii, A.E.; Marchenko, T.N. Vodorodnaya Svyaz' (Hydrogen Bond); Sokolov, N.D., Ed.; Nauka: Moscow, Russia, 1981.

97. Krygowski, T.M.; Zachara-Horeglad, J.E. Resonance-assisted hydrogen bonding in terms of substituent effect. Tetrahedron 2009, 65, 2010-2014. [CrossRef]

98. Sanz, P.; Mó, O.; Yanez, M.; Elguero, J. The effects of C by N replacement on the hydrogen bonding of malonaldehyde: $N$-formylformimidic acid, $N$-(hydroxymethyl)formamide and related compounds. Phys. Chem. Chem. Phys. 2009, 11, 762-769. [CrossRef] [PubMed]

99. Palusiak, M.; Simon, S.; Sola, M. Interplay between intramolecular resonance-assisted hydrogen bonding and aromaticity in $o$-hydroxyaryl aldehydes. J. Org. Chem. 2006, 110, 5241-5248. [CrossRef] [PubMed]

100. Filarowski, A.; Kochel, A.; Kluba, M.; Kamounah, F. Structural and aromatic aspects of tautomeric equilibrium in hydroxy aryl Schiff bases. J. Phys. Org. Chem. 2008, 21, 939-944. [CrossRef]

101. Kluba, M.; Lipkowski, P.; Filarowski, A. Theoretical investigation of tautomeric equilibrium in ortho-hydroxy phenyl Schiff bases. Chem. Phys. Lett. 2008, 463, 426-430. [CrossRef]

102. Albayrak, C.; Sevincek, R.; Petek, H.; Aygun, M. Aromaticity balance, $\pi$-electron cooperativity and H-bonding properties in tautomerism of salicylideneaniline: The quantum theory of atoms in molecules (QTAIM) approach. J. Mol. Model. 2011, 17, 1295-1309. 
103. Houjou, H.; Motoyama, T.; Banno, S.; Yoshikawa, I.; Araki, K. Experimental and Theoretical Studies on Constitutional Isomers of 2,6-Dihydroxynaphthalene Carbaldehydes. Effects of Resonance-Assisted Hydrogen Bonding on the Electronic Absorption Spectra. J. Org. Chem. 2009, 74, 520-529. [CrossRef] [PubMed]

104. Krygowski, T.M.; Cyranski, M.K. Structural aspects of aromaticity. Chem. Rev. 2001, 101, 1385-1419. [CrossRef] [PubMed]

105. Zubatyuk, R.I.; Shishkin, O.V.; Gorb, L.; Leszczynski, J. Homonuclear versus Heteronuclear Resonance-Assisted Hydrogen Bonds: Tautomerism, Aromaticity, and Intramolecular Hydrogen Bonding in Heterocyclic Systems with Different Exocyclic Proton Donor/Acceptor. J. Phys. Chem. A 2009, 113, 2943-2952. [CrossRef] [PubMed]

106. Zubatyuk, R.I.; Volovenko, Y.M.; Shishkin, O.V.; Gorb, L.; Leszczyński, J. Aromaticity-Controlled Tautomerism and Resonance-Assisted Hydrogen Bonding in Heterocyclic Enaminone-Iminoenol Systems. J. Org. Chem. 2007, 72, 725-735. [CrossRef] [PubMed]

107. Wu, J.I.; Jackson, J.E.; Schleyer, P.v.R. Reciprocal Hydrogen Bonding-Aromaticity Relationships. J. Am. Chem. Soc. 2014, 136, 13526-13529. [CrossRef] [PubMed]

108. Sobczyk, L.; Grabowski, S.; Krygowski, T.M. Interrelation between H-Bond and Pi-Electron Delocalization. Chem. Rev. 2005, 105, 3513-3545. [CrossRef] [PubMed]

109. Sucharda-Sobczyk, A.; Sobczyk, L. Tautomerism of 6-nitro derivatives of ortho Mannich-bases. J. Chem. Res. 1985, 6, 208-209.

110. Konopacka, A.; Filarowski, A.; Pawelka, Z. Solvent influence on the transformation of intramolecular hydrogen bonds in 2-hydroxy-5-methyl-3-nitroacetophenone. J. Solut. Chem. 2005, 34, 929-945. [CrossRef]

111. Kozlecki, T.; Tolstoy, P.M.; Kwocz, A.; Vovk, M.A.; Kochel, A.; Polowczyk, I.; Tretyakov, P.Y.; Filarowski, A. Conformational state of $\beta$-hydroxynaphthylamides: Barriers for the rotation of the amide group around $\mathrm{CN}$ bond and dynamics of the morpholine ring. Spectrochim. Acta A 2015, 149, 254-262. [CrossRef] [PubMed]

112. Pertlik, F. Crystal structures and hydrogen bonding schemes in four benzamide derivatives (2-hydroxy-benzamide, 2-hydroxy-thiobenzamide, 2-hydroxy- $N, N$-dimethyl-benzamide, and 2-Hydroxy- $N, N$-dimethyl-thiobenzamide). Monatsh. Chem. 1990, 12, 129-139. [CrossRef]

113. Johnstone, R.D.L.; Lennie, L.R.; Parker, S.F.; Parsons, S.; Pidcock, E.; Richardson, P.R.; Warren, J.E.; Wood, P.A. High-pressure polymorphism in salicylamide. CrystEngComm 2010, 12, 1065-1078. [CrossRef]

114. Kawski, P.; Kochel, A.; Perevozkina, M.G.; Filarowski, A. The intramolecular hydrogen bond in 2-hydroxy-benzamides. J. Mol. Struct. 2006, 790, 65-73. [CrossRef]

115. Mahmudov, K.T.; Pombeiro, A.J.L. Resonance-Assisted Hydrogen Bonding as a Driving Force in Synthesis and a Synthon in the Design of Materials. Chem. Eur. J. 2016, 22, 16356-16398. [CrossRef] [PubMed]

116. Hynes, J.T.; Klinman, J.P.; Limbach, H.H.; Schowen, R.L. (Eds.) Hydrogen-Transfer Reactions; Wiley-VCH Verlag GmbH \& Co. KGaA: Weinheim, Germany, 2007.

117. Lynden-Bell, R.M.; Morris, S.C.; Barrow, J.D.; Finney, J.L.; Harper, C.L., Jr. (Eds.) Water and Life. The Unique Properties of $\mathrm{H}_{2} \mathrm{O}$; CRC Press, Taylor \& Francis Group: Boca Raton, FL, USA, 2010.

118. Maréchal, Y. The Hydrogen Bond and the Water Molecule: The Physics and Chemistry of Water, Aqueous and Bio Media; Elsevier: Amsterdam, Oxford, UK, 2007.

119. Kirov, M.V. Hydrogen-bond-reversal symmetry and its violation in ice nanotubes. Acta Cryst. A 2016, 72, 395-405. [CrossRef] [PubMed]

120. Grabowski, S.J. What is the covalency of hydrogen bonding? Chem. Rev. 2011, 111, 2597-2625. [CrossRef] [PubMed]

121. Limbach, H.H.; Denisov, G.S.; Shenderovich, I.G.; Tolstoy, P.M. Proton Tautomerism in Systems of Increasing Complexity: Examples from Organic Molecules to Enzymes. In Tautomerism: Concepts and Applications in Science and Technology; Antonov, L., Ed.; Wiley-VCH Verlag GmbH \& Co. KGaA: Weinheim, Germany, 2016.

122. Warncke, G.; Fels, S.; Brendler, E.; Böhme, U. Tautomerism in N-(2-hydroxy-1-naphthylidene)amino acids and the search for an answer to the difficult question about where the proton belongs. J. Mol. Struct. 2016, 1117, 37-48. [CrossRef]

123. Scheiner, S. Hydrogen Bonding: A Theoretical Perspective; Oxford University Press: New York, NY, USA, 1997.

124. Dubonosov, A.D.; Bren, V.A.; Minkin, V.I. Enolimine-Ketoenamine Tautomerism for Chemosensing. In Tautomerism: Concepts and Applications in Science and Technology; Antonov, L., Ed.; Wiley-VCH Verlag GmbH \& Co. KGaA: Weinheim, Germany, 2016.

125. Sheikhshoaie, I.; Fabian, W.M.F. Theoretical Insights into Material Properties of Schiff Bases and Related Azo Compounds. Curr. Org. Chem. 2009, 13, 149-171. [CrossRef] 
126. Scheiner, S. The Pnicogen Bond: Its Relation to Hydrogen, Halogen, and Other Noncovalent Bonds. Acc. Chem. Res. 2013, 46, 280-288. [CrossRef] [PubMed]

127. Tan, J.; Namuangruk, S.; Kong, W.; Kungwan, N.; Guo, J.; Wang, C. Manipulation of Amorphous-to-Crystalline Transformation: Towards the Construction of Covalent Organic Framework Hybrid Microspheres with NIR Photothermal Conversion Ability. Angew. Chem. Int. Ed. 2016, 128, 14185-14190. [CrossRef]

(C) 2016 by the authors; licensee MDPI, Basel, Switzerland. This article is an open access article distributed under the terms and conditions of the Creative Commons Attribution (CC-BY) license (http:/ / creativecommons.org/licenses/by/4.0/). 